\title{
Can social work education keep up to the demands of geriatric social work
}

\section{Opinion}

Globally, the demographic transformation of an exponentially growing, elderly population is ubiquitous. ${ }^{1}$ Within the 65 -plus cohort, the 'old-old' or those aged 85-plus are the fastest growing group. By 2030, in the United States, it is proposed that the number of elderly, aged 65-plus is expected to double, rising to 70-million and the projected 'old-old' population will rise to some approximately 14-million. ${ }^{2}$ In the 2016 Occupational Outlook Handbook, published by the U.S. Bureau of Labor Statistics, ${ }^{3}$ social work employment is projected to grow $12 \%$ from 2014-2024, faster than average for all listed professions (BoLS, 2016). Such employment growth in social work, will be primarily driven by increased demands for health care, mental health care, and social services, but will vary by specialty (BoLS, 2016). The demands for social work gerontologists or gerospecialists, those trained to work with the elderly are currently high demand. ${ }^{4}$

The degree granting institutions which educate and train social workers to practice in America include:

A. Community and/or technical colleges, offering:

i. Associate degrees in social work or family studies.

ii. Certificates in various areas such as health, mental health, human services, gerontology, behavioral counseling, family studies, child care work and youth work.

iii. Pre-social work coursework to transition directly into baccalaureate programs in social work. ${ }^{5}$

B. Bachelor's degree: the BSW or BASW is the Council on Social Work Education's (CSWEs) accredited

Entry-level first practice degree.

C. Master's degree: the accredited MSW (the main degree title), MSSW, MSS degrees offer advanced

Knowledge and skills typically in macro or micro areas of practice with individuals, small groups, families, social service agencies, and communities. This is deemed by the profession to be the final and culminating practice degree for social workers.

Within these three practice degrees, the curriculum. ${ }^{6}$ Structure and flexibility to pursue additional specialty education varies considerably by both the degree, and how it is taught in different schools. In general, community colleges and accredited graduate programs have the greater likelihood within their curricula of supplementing their degree programs with minor specializations in health, mental health, substance abuse, marriage and families, public health, child welfare, school of social work, and gerontology.

In graduate schools such specialization training is typically offered by way of an additional certificate which typically includes a 3-4 course package of in-class courses, which are likely to be
Volume I Issue I - 2017

\author{
Michael J Holosko \\ Department of Pauline M Berger, Professor of Family and Child \\ Welfare, University of Georgia, Georgia
}

\begin{abstract}
Correspondence: Michael J Holosko, Department of Pauline M Berger Professor of Family and Child Welfare, The University of Georgia, School of Social Work, 279 Williams Street, Athens, Georgia,Email mholosko@uga.edu
\end{abstract}

Received: September 20, 2016 | Published: January 30, 2016

electives, and perhaps a field internship in the student's certificate area of interest. The demands of graduate course work include 900 hours of internship coupled with a sequential lock-step course package requirement, and a limited elective schedule that leaves very little room within the social work curriculum for obtaining any in-depth knowledge for the granted certificates offered in the various fields noted above (CSWE, 2015). Indeed, it is rather superficial, at best. And herein lays the rub, as is reflected in the title of this opinion piececan schools of social work stay abreast of the increasing demands for specialized training needed to serve our rapidly growing and aging population? The schism between the rapidly changing and increasing demographics of the elderly, coupled with their complex patient needs and limited resources, demands better quality education and training for social work students, who call themselves case-managers, gerontologists, or geriatric social workers.

According to one of the top-ranked social work programs in the U.S., the University of Southern California, noted on their recent (March 2, 2016) website was that the most popular social work career among the top- five ranked, was the medical/public health field (USC, 2016). They also noted that this field of practice will grow some $22 \%$ through 2018; the highest rate for job demands in the field of social work. It is no secret that this is the same domain where vulnerable elderly clients are likely to show up on the caseloads of social workers. Thus, social work gerontologist will be employed in a range of specialized medical and social facilities and personnel that provide elderly patient care which minimally include: orthopedics, psychiatry, occupational therapy, physical therapy, renal dialysis, emergency rooms, nursing homes, rehabilitation facilities, assisted living. ${ }^{7}$ facilities, hospices, community service providers, insurance companies, attorneys, financial officials, mental health workers, housing personnel, and family support workers - to name a few. Now returning to the point of inadequate social work education, as an example-not one Master's program that I am aware of in the U.S. today offers a course on basic medical terminology-deemed as necessary content to do any gerontology work with, and in, the above named institutions and specialists. 
Despite the aforementioned delimiting nature of our current social work curricula, the existing curriculum indeed appear relatively minimalist for offering any specialty training for either BSW or MSW gerontological inclined social work graduates. However, it is not just the curricula that are delimited, as there are very few faculties who have the knowledge needed to effectively teach aging content to social work students. ${ }^{8-9}$ And, as noted by the dates in these references, this reality has not changed for some 20 years.

Unfortunately, these are not the only impediments to educating today's social workers to work effectively with the elderly. Within the curriculum itself, students are unlikely to have any specialized placement opportunities to integrate their learning, there are few field instructors competent in such areas to supervise students effectively, and there are very few opportunities for practice research deemed as ethically necessary to assess the efficacy of our work with such clients. And plain and simple, that is our social work gerontological educational reality, today!

\section{Concluding remarks}

As we are acutely aware when practicing our noble social work craft with at-risk populations on a daily basis, there are many contextual realities in our external environments that influence and drive why, and how we do our work. ${ }^{10}$ In the field of gerontology in the U.S., four major national initiatives have driven the demand for highly trained and specialized social workers to work effectively with elderly clients. These include: the Institute of Medicine's 2008 report which identified the social work. ${ }^{11}$ Profession to be critical members of the geriatric workforce. ${ }^{12}$ It also called for enhanced geriatric competence of the general work force, as well as increased recruitment and retention of geriatric specialist, including social workers (CFHC, 2008). The Affordable Care Act. ${ }^{13}$ which in subsection 3021 established the Center for Medicare and Medicaid Innovation. ${ }^{14}$

Whose mission calls for innovative models of care to address the most vulnerable older adults, the dual eligible's [individuals who receive both Medicare and Medicaid benefits]. Third the John A Hartford Foundation's Geriatric Social Work Initiative in 2014 whose purpose was "to increase the competence of social workers to improve the care and well-being of older adults and their families (GSWI, 2014).Their initiatives used innovative strategies aimed at: a) educating social work students to specialize in geriatrics, b) recruiting students to specialize in geriatrics, and c) supporting academic social workers to conduct research and teach in geriatrics. ${ }^{15}$ Finally here, the NASW recently developed an Aging Initiative to raise awareness about the breadth of geriatric social work practice, and increase the numbers of professionally trained and credentialed social workers who served older adults and their families. ${ }^{16}$

It is frustrating to continue to see areas of practice that our profession has the expertise to be effective in, and make a difference in the lives of people daily. ${ }^{9}$ However, our current curricular, our lack of topical post-degree professional education and training, our limited on-the-job training, and our limited supervision to do such specialized work-all need to be bolstered by more effective curriculum knowledge, education, and training. The apparent schism existing between our current inadequate education and training, and the specialized demands of this growing practice field, need to be much better addressed by social work if we are to have any professional traction in this field.

\section{Acknowledgements}

None.

\section{Conflict of interest}

Author declares there is no conflict of interest in publishing the article.

\section{References}

1. Mirkin B, Weinberger B The demography of population ageing.

2. National Association of Social Workers. Aging. 2016.

3. Bureau of Labor Statistics, U.S. Department of Labor, Occupational Outlook Handbook, Edition, Social Workers.

4. Holosko M, Feit M ed. Social Work Practice with the Elderly, 3rd ed Toronto, Ontario; The Canadian Scholar's Press Inc. 2004.

5. Council on Social Work Education. Educational Policy and Accreditation Standards (EPAS) for Baccalaureate and Masters Social Work Programs. 2015

6. University of Southern California. The five most popular social work careers. 2016

7. Institute on aging. Living longer. 2016.

8. Holosko M J, Heckman J. Interventions with the elderly In L. Rapp-Paglicci, W. Rowe ed. Evidence-based social work practice. New York, Haworth Press. 2007

9. Holosko M. The inclusion of gerontology content into undergraduate social work curricula in Australia and New Zealand. Gerontology and Geriatrics Education. 1995;15(4):5-20.

10. Feit MD, Holosko M. Distinguishing Clinical from Upper Level Management in Social Work. London; 2013.

11. Geriatric Social Work Initiative. Hartford National Center on gerontolog ical social work excellence. 2014

12. Committee on the Future Health Care workforce for older Americans Institute of Medicine. Retooling for an gaining America: Building the health care workforce. Washington, DC: The National Academies Press. 2008

13. Patient Protection and Affordable Care Act. C.F.R. 2010;111-148

14. CMS Innovation Center. Center for Medicare and Medicaid Innovation. 2014.

15. Rizzo VM , Rowe JM. Cost-effectiveness of social work services in aging: An updated systematic review. Research on Social Work Practice. 2016;26(6):653-667.

16. Department of Economic and Social Affairs (DESA) Population Division. World Population Ageing. 2016;1950-2050. 